\title{
INFORMEDNESS OF COLLEGE STUDENTS AS BANK CUSTOMERS
}

\author{
Gande Surya *1凶 \\ ${ }^{* 1}$ Integrated MA economics student, University of Hyderabad, India
}

DOI: https://doi.org/10.29121/granthaalayah.v8.i6.2020.418

Article Type: Research Article

Article Citation: Gande Surya. (2020). INFORMEDNESS OF COLLEGE STUDENTS AS BANK CUSTOMERS. International Journal of Research -GRANTHAALAYAH, 8(6), 276-279. https://doi.org/10.29121/granthaa layah.v8.i6.2020.418

Received Date: 03 April 2020

Accepted Date: 30 June 2020

Keywords:

Bank Customers

Dispute

Citizen Charter of Bank

Banking Ombudsman

Bank Statement

Interest on Deposits

\begin{abstract}
Banks are the institutions where most of the people put their hardearned money in. But do they really know about banks - their services, their terms and conditions, their tariff plans, their communications and the dispute resolution mechanisms? This study tried to find out this by, interviewing 100 young college-going bank customers. The surprising results of this study led to some suggestions which require immediate implementation.
\end{abstract}

\section{INTRODUCTION}

The customer's knowledge of the service, service provider and other players in the service market is called customer awareness. An informed customer can make decisions that give him the maximum benefit. This informedness brings the need for continuous improvement in products/ services, making only the fittest to survive. This, in turn, helps in the overall prosperity of the economy.

Bank services include accepting deposits and extending loans amongst others. Accepting deposits account for a large consumer base and volume. The modern banking industry of India dates back to the colonial era. The banking industry in India is so large that it accounts for over 130 commercial banks with aggregate deposits amounting to USD 950 billion (as of 2013). With the industry being this large it becomes important for the customers to be:

- Aware of the basic terms and conditions of the bank service.

- Aware of the tariff plan of the bank services.

- Aware of dispute resolution mechanisms.

- Able to understand basic bank communication (Bank statement/ SMSs). 
This awareness will allow consumers to make the best choices. With customers being informed it almost becomes obligatory for banks to improve their services. This benefits the banking industry and the economy as a whole. This study is an attempt to examine the level of customer awareness in the baking sector in India.

\section{OBJECTIVES OF THE STUDY}

The study has been conducted with the following objectives:

1) Customer awareness of basic terms and conditions of bank services.

2) Customer's ability to understand of bank's communication.

3) Customer awareness of the dispute resolution mechanism.

4) Suggestions for improvement of the banking industry.

\section{METHODOLOGY}

Data has been collected from both primary and secondary sources for the study.

Primary data has been collected using a questionnaire and one to one interview of students (UG Students) of three different streams viz. Science, Arts and Commerce of reputed colleges and universities in Telangana. The sample is a randomly selected respondents of sample size - 100.

Secondary data has been collected from various books, journals and articles.

\section{RESULTS AND DISCUSSION}

The level of the customer's awareness is judged based on the following parameters:

- Are they aware of the basic terms and conditions of the service.

- Are they aware of the service tariff plans of their bank.

- Do they understand SMS/ Bank statements of banks.

- Are they aware of the dispute resolution mechanism.

The results of the study were surprising because Almost none of the customers were aware of the existence of citizen charters of banks which, contains the general/ basic terms and conditions of banks. Most of them even after using multiple bank accounts (55\% of respondents)/ using bank accounts for more than 2 years (88\% of respondents) are not even aware of the interest paid by their bank. For a rational customer the primary objective of a deposit is interest, and not being aware of it defeats the whole purpose of a deposit. Only a minute fraction of them was aware of the dispute resolution mechanisms. And Most of them did not understand the basic communication from banks.

The results of the study can be easily understood using the charts below:

Figure 1 shows that $68 \%$ of the respondents did not know about the interest paid by their banks. Which is basically the most important parameter before making an investment/ deposit.

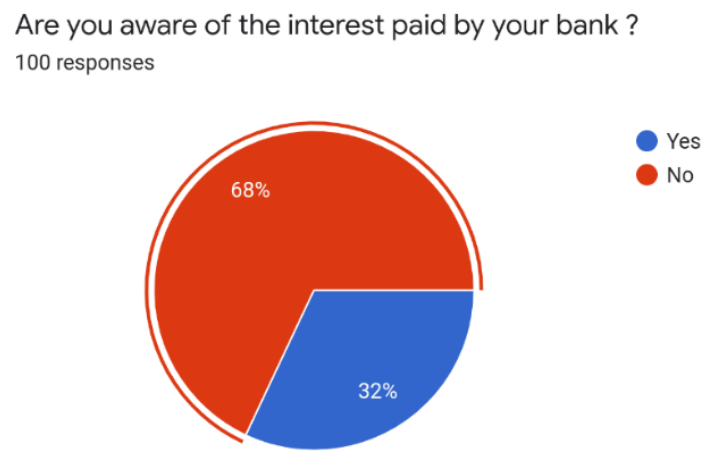

Figure 1: Awareness on bank interest 
Figure 2 shows the ignorance of customers, even of the existence of a bank's citizen charter - which contains almost all the basic terms and conditions.

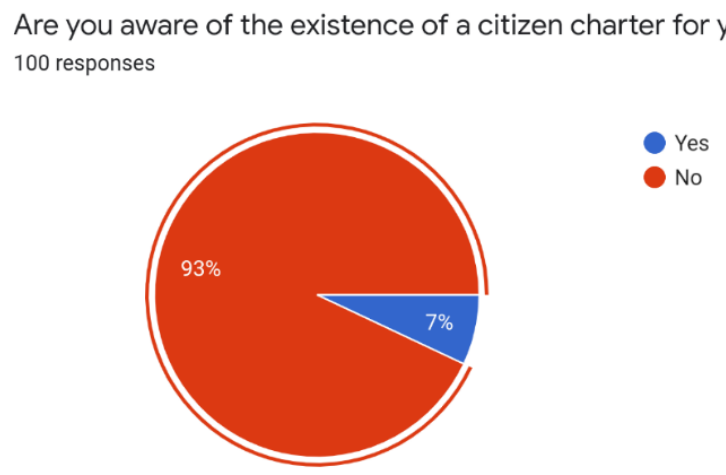

Figure 2: Awareness of bank citizen charter

Figure 3 shows the effectiveness of bank communication. Not even one in four respondents understand the terms - debit/ credit which is used in most bank communications - bank statements/ SMSs
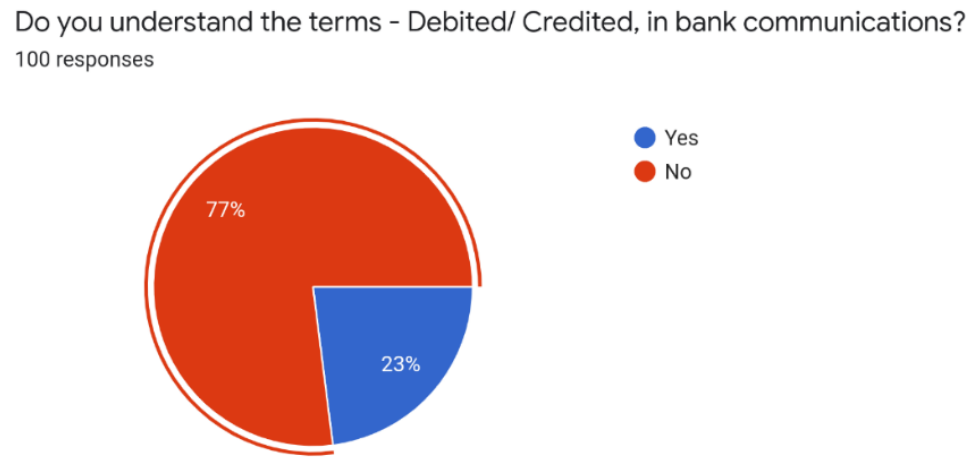

Yes

Figure 3: Understandability of bank communication

Figure 4 and 5 show the ignorance of bank customers of Dispute resolution mechanisms and the annual maintenance charges of banks respectively.
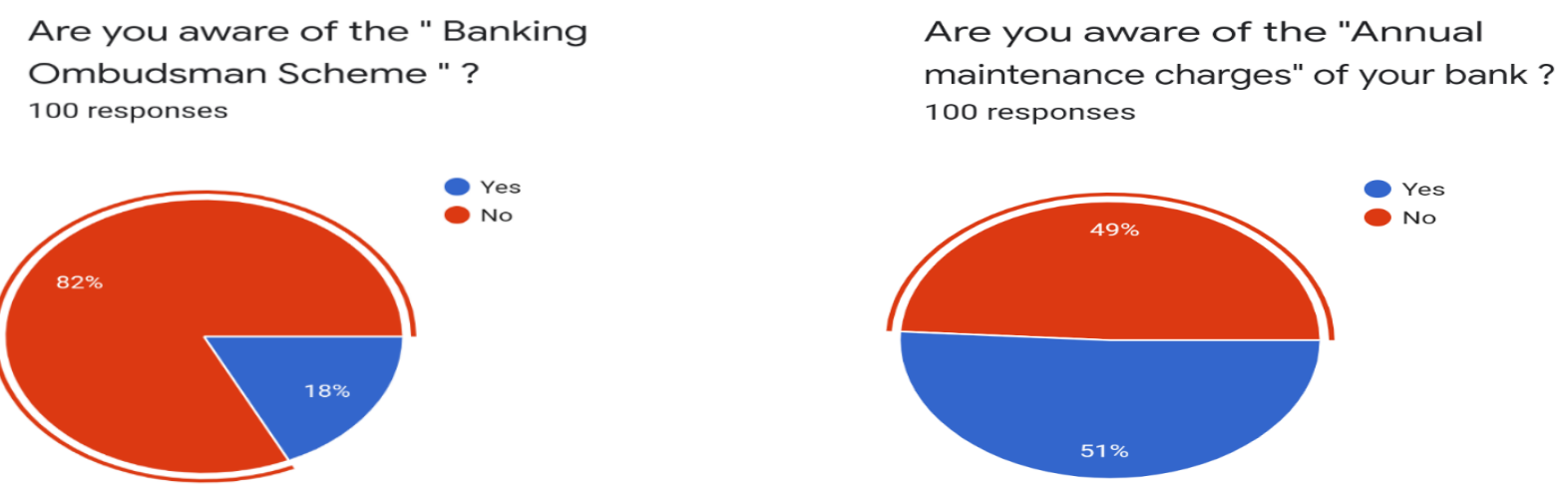

Figure 4: Awareness of banking Ombudsman scheme. Figure 5: Awareness of Annual Maintenance Charges. 
This cumulatively suggests that customers are not aware of:

- what they get in return of their deposit.

- They do not know the basic terms and conditions of the service.

- They don't understand basic bank communication.

- Also, they don't know where to go if there is a dispute with the bank.

In a nutshell, they almost know nothing of banking, even after banking for more than two years now. If this is case with University/ College students the situation of other customers in the society could be unimaginable.

\section{SUGGESTIONS}

This study was an attempt to understand the awareness levels of bank customers. The results of the study lead to the following suggestions:

- Increase awareness about the banking Ombudsman scheme by the banking industry.

- Respective banks have to make people aware of their terms and conditions (including tariff plans).

- Banks have to change their terminology (eg. Debit/ Credit in bank statements/ SMSs) to communicate efficiently with their customers.

- Personal finance has to be made, part of the curriculum in higher education irrespective of their discipline.

\section{CONCLUSION}

Though the government is taking active steps to protect bank customers, they are far from saturation. People are not even aware of the basic things. This gives banks an opportunity to exploit their customers. This also results in people making irrational decisions, which is not good for the economy as a whole and consumers in particular. So, it perhaps becomes imperative for the authorities to consider to above suggestions.

\section{SOURCES OF FUNDING}

None.

\section{CONFLICT OF INTEREST}

None.

\section{ACKNOWLEDGMENT}

None.

\section{REFERENCES}

[1] Kangkana Chaudhury. (2017). “CONSUMER AWARENESS AMONG COLLEGE STUDENTS.” International Journal of Research - Granthaalayah, 5(6), 223-230. https://doi.org/10.5281/zenodo.820525.

[2] Nitin Night, Kumar Gangwar, Kaushal Kishor. (2018). "AWARNESS IF CONSUMER RIGHTS AMONG STUDENTS." International Conference on Recent Innovation in Management, Engineering, Science and Technology - RIMEST. www.conferenceworld.in.

[3] “STATISTICAL TABLES RELATING TO BANKS IN INDIA 2012- 13.” Reserve Bank of India (2013). 